\title{
The Human Being as a Creator of (in) Human Life: The Example of Mary Shelley's Frankenstein; or, the Modern Prometheus
}

\author{
Anna C. Rédei * \\ Centre for Languages and Literature, Division of Linguistics and Cognitive Semiotics, Lund University, Lund, Sweden
}

Humans have an inquiring mind. Throughout history, one may find documentation that shows on human curiosity, and our drive to stretch boundaries to satisfy it. Thus, this is not something that characterizes our time in any particular way. Sources, for instance, from the 13th century can serve as good examples that support such an assumption. Mary Shelley's novel from the 19th century, "Frankenstein; or, the modern Prometheus," might perhaps be the most known commentary to that boundary stretching, which continues in a slightly new form in the ongoing debate and the popular culture within the scientific community. Shelley's narrative about the scientist Frankenstein and his

OPEN ACCESS

Edited by: Olaf Witkowski,

Cross Labs, Japan

Reviewed by:

Eileen Hunt Botting,

University of Notre Dame,

United States

Lilla Maria Crisafulli,

University of Bologna, Italy

*Correspondence:

Anna C. Réde

Anna.cabak_redei@semiotik.lu.se

Specialty section:

This article was submitted to

Digital Impacts,

a section of the journal

Frontiers in Human Dynamics

Received: 31 May 2021 Accepted: 12 January 2022 Published: 15 February 2022

Citation:

Rédei AC (2022) The Human Being as a Creator of (in) Human Life: The

Example of Mary Shelley's

Frankenstein; or, the

Modern Prometheus.

Front. Hum. Dyn 4:718435.

doi: 10.3389/fhumd.2022.718435 Creature has continued to interest the audience. Through adaptations to film, the story has reached many new generations of cinema goers. However, new interpretations have altered some aspects the original message. Shelley's conception of the monstrous was more complex than today when parts of the narrative have been downplayed and others have been upscaled.

Keywords: Mary Shelley, Frankenstein myth, history of ideas, psychology, film

\section{INTRODUCTION}

Mary Shelley's (1797-1851) "Frankenstein; or, the modern Prometheus" was first published in 1818 (Figure 1) and is a fictive story about the scientist Frankenstein and his Creature (also called the Monster). The novel was an immediate success in the popular culture. Already during the 19th century, it was adopted for the theater where a new interpretation of the narrative emerged that continued into the film medium already in 1910 (16 min long). Thus, a novel has continued to fascinate the audience in our time.

However, the focus in later adaptations has been put on Frankenstein's scientific obsession with creating life - an obsession that eventually leads to a fatal trespass of ethical and religious values-at the expense of questions that might have occupied Shelley herself even more: namely, the problem of responsibility and the limits between what can be considered as human and what cannot. Because of that reorientation, perhaps, in the popular culture, the Creature in the novel has been reduced to a monster and lost some of the complexity that Mary Shelley gave it. The Monster has been deprived of the human qualities that were characteristic for the Creature, the Monster grunts in the film in contrast to the Creature in the novel, who puts an enormous effort into learning the human language of which he is so fascinated.

This essay starts with a presentation of the framework of the novel and, thereafter, an account of the scientific context in which Mary Shelley worked and a short overview of the monster concept in 


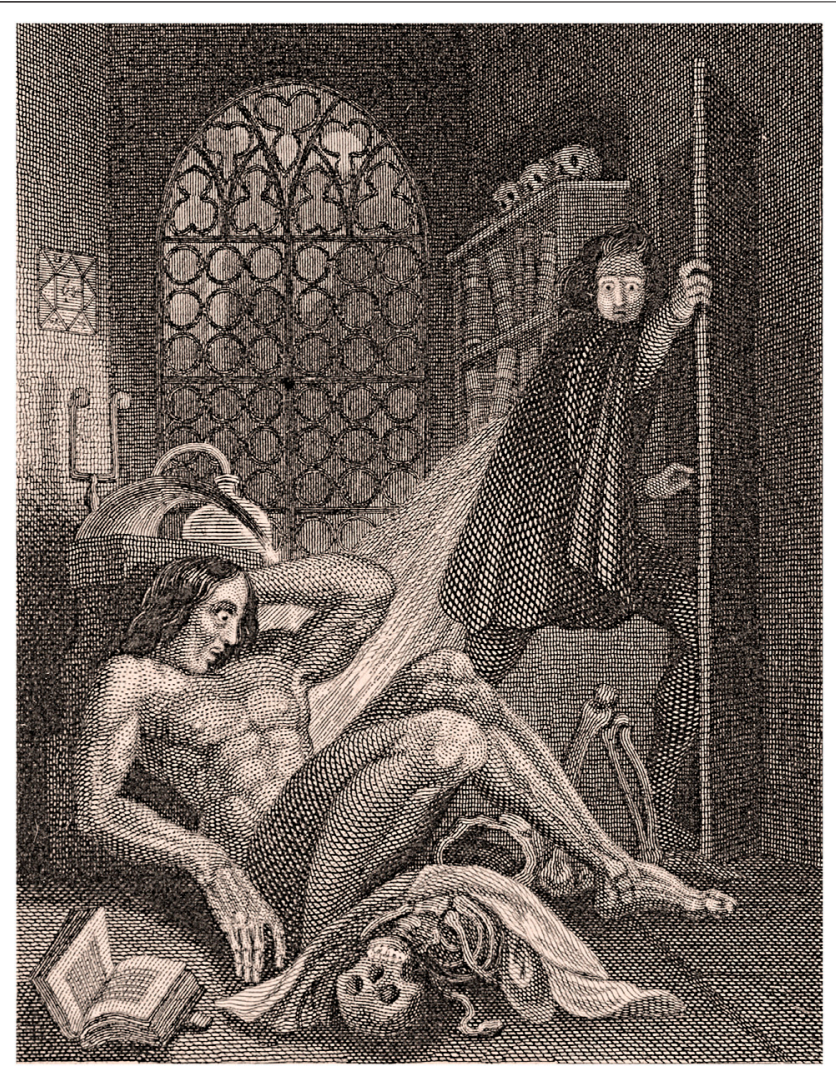

FIGURE 1 | Victor Frankenstein becoming disgusted at his creation. Frontispiece 1831 edition. Page URL: https://commons.wikimedia.org/wiki/ File\%3AFrontispiece_to_Frankenstein_1831.jpg.

the history if ideas follow. In addition, an overview of the Attachment theory is included because the aspects of Mary Shelley's portraiture of the relation between Frankenstein and his Creature benefit from being interpreted from a psychological point of view. These accounts are necessarily short and only bring up a few points for the purpose of this essay. The essay then concludes with a comparative analysis of the novel and its first film adaption in 1931 with the aim to answer the question of how the interpretations of the Frankenstein character have evolved and been adopted: Has the Frankenstein character comes into the fore as a new modern monster type, but less monstrous than Mary Shelley's original portraiture?

To shed some light on that question, a hermeneutic approach in the analysis of texts and films has been used. More specifically, the point of departure is the idea that, when a cultural artifact, be it a novel or film for instance, these are produced by an artist (in a specific sociocultural context) for a public (the receivers) and will be interpreted with the aid of the semiotic resources - the means that are available in the process of interpretation for the receiver-in a particular sociocultural context, that might be different from the artist's, in time and place. For instance, the modern reader of "Frankenstein; or, the modern Prometheus" would have another pre-understanding of its meaning than the 19th century reader; therefore, we would

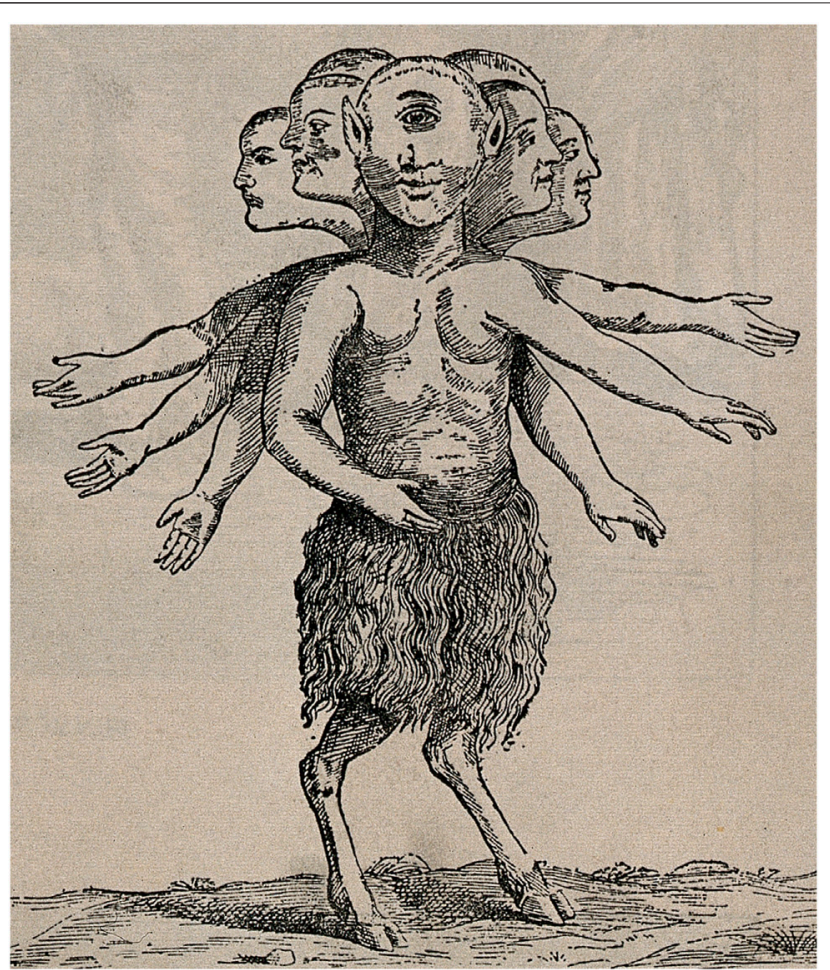

FIGURE 2 | A fantastic monster: A cyclops with multiple heads and arms. https://commons.wikimedia.org/wiki/File:Spanish_monster_found_in_ 1655_art_detail,_from-_A_fantastic_monster;_a_cyclops_with_multiple_ heads_and_arms_Wellcome_V0007455_(cropped).jpg.

need to understand our pre-understanding and overcome it, so to speak, in the process of interpreting the text through putting ourselves in the position of the other, in the other's sociocultural context. To do that, we need to reconstruct the context in which a particular artifact was produced to interpret its possible meaning, to be able to interpret the artist's preunderstanding of the world, reflected in the artifact. Ontologically, hermeneutics takes the position that we do not have access to "reality" unmediated, only via interpretation from a subjective point of view determined by personal and sociocultural factors (Ricoeur, 1970; Eco, 1990; PresskornThygesen, 2012). Now, what is Mary Shelley's “Frankenstein; or, the modern Prometheus" about?

\section{THE FRAMEWORK OF THE NOVEL}

Shelley's novel was published in 1818 and 1831, in a slightly revised edition (Figure 1). The book is divided into three parts and the first starts with Walton's narrative from his expedition ship far north in the seas close to the North Pole. There, Walton saved Frankenstein who, in his chase for the Creature, has fallen into the sea when the ice broke. Walton is anxious to become his friend, and, eventually, Frankenstein tells him the story behind the chase. Walton's rendering of Frankenstein's life story initiates the narrative of the novel and ends it by telling the story of his 


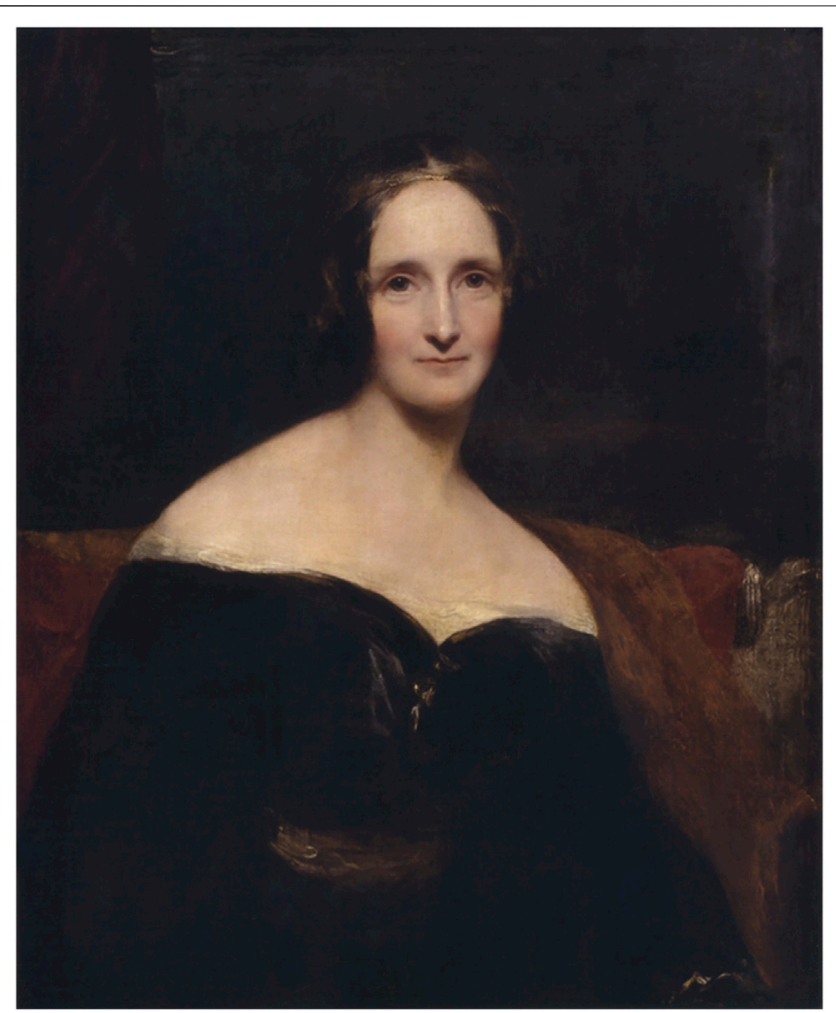

FIGURE 3 | Mary Wollstonecraft Shelley by Richard Rothwell (1800-1868). https://commons.wikimedia.org/wiki/File\% 3ARothwellMaryShelley.jpg

meeting with the Creature who escapes through the window of the cabin where the coffin with Frankenstein's remains were and vanishes out in the dark sea. Walton's story is given in the form of letters that he writes to his sister. Walton shares some features with Frankenstein. His expedition to the North Pole might be said to be the result of a similar scientific obsession that drove Frankenstein to create life. The difference is that Walton gives up when the sailors were close to mutiny due to the hardship on board, changes course, and turns back. This limitation is what Frankenstein lacks.

In the second part of the novel, the reader takes part of the Creature's story. A story is about suffering and seeking for human closeness and love that his creator denied him. At a certain point in the narrative, the Creature realizes what he looks like and slowly he understands why people-and Frankenstein himself-flees him. However, the Creature does not give up his rights to love and asks Frankenstein to create a wife for him. Frankenstein consents, reluctantly, to the request but postpones it until he finally realizes that he needs to do it. In the last moment, he refuses to carry through with the experiment and the Creature responds with great fury. The woes and disappointments turn to hate, and the Creature is ceased by a strong vindictiveness toward Frankenstein that costs him the life of his newly wedded wife. However, before that tragedy, the Creature caused great misfortunes-in the beginning accidently but eventually knowingly and Frankenstein's best friend Henry
Clerval became one of his victims. The third and last part of the novel is a dialogue where the voices of Frankenstein, Walton, the Creature, and others shed light on the tragedy that in the end takes Frankenstein's life and possibly also the Creature's who escapes out of the cabin window of Walton's ship. Frankenstein himself had died earlier because of the long chase and the losses of his wife Elisabeth, his father (who died mourning the loss of Elisabeth), his best friend, a dear younger brother, and a faithful servant in the household. In the end, Frankenstein and the Creature's destruction became each other's misfortune. Now, taking a step back, what did the emerging natural science look like at the time for Shelley's novel?

\section{SCIENCE AND MONSTERS DURING THE ENLIGHTENMENT: A SHORT OVERVIEW}

The philosophy of mathematics during the 18th century brought forth scientific ideals that were represented in concepts like "L'Homme machine." The concept was as a result of the philosopher and materialist philosopher La Metttrie's (1709-1751) elaboration of Descartes' (1596-1650) work that lead to the idea that there was no difference between animals and human beings, both were machines (however, Descartes himself had made a difference between the two, due to the fact that, according to him, humans had souls, but, apart from that, both were mechanistic). However, La Mettrie, in his "L'Homme machine" wrote: "a machine which can no longer be regarded as impossible, especially in the hands of a new Prometheus" (Hindle, 2003, p. xxxiv). La Mettrie had settled with God and God's existence that he doubted-the latter being an important part of the enlightenment and its struggle for freedom from religious domination and dogmas.

Important to mention for the purpose of this essay is galvanism. It was a method that got its name from the Italian physician and natural philosopher Luigi Galvani (1763-1834), who, at the end of the 18th century, conducted experiments on frogs. He concluded that animals and human beings consisted of a type of electrical circuits that were crucial to the viability and that could be manipulated from the outside. On the basis of these conclusions, the idea that the human being could resurrect animals and humans from the dead was born. In the beginning of the 19th century, galvanic experiments were particularly popular in cities like Paris and London. They were especially popular in London where the rates of delinquency were high and punishments are severe. The explanation to this was that galvanic experiments could only be conducted on bodies from executed criminals; thus, the access to bodies was good because the crimes rates were high. The criminal monster was also a figure that preoccupied the revolutionaries in the years leading up to the Revolution and was intensified at the end of the 18th century in France.

In the history of ideas, the concept of the monster (Figure 2) can be traced back to the late 12th century and the Arnstein Bible, visualized in a series of drawings called "Monstrous Races," signifying the Other (Wright, 2013). What, in that concept, could shed some light on Mary Shelley's "creation"? 


\section{The Human Monster}

The monster figure represents the Other, the Other that is alien to us. As such, the monster is somebody with whom we are not in dialogue, who cannot provide us with any information of any sort valuable to us. In cultural semiotics, the monster, so defined, is equivalent to the notion of Alius (Rédei, 2007; Sonesson, 2016). Alexa Wright writes about the human monster:

"as an embodiment of social, moral or ontological disorder. Their hybrid bodies, which combine human and animal, male and female, cultural and natural elements, operate as signifiers of the known and unknown" (Wright, 2013, p. 16).

The human monster, according to Foucault (2003), represents the violations of the laws of nature and society, and the monster belongs to the "juridico-biological domain" (Foucault, 2003, p. 56). The monster violates the law, but the law stays numb in front of the monster's atrocities. The monster is an impossible creature, violating the laws (religious, civil, or moral) but being, at the same time, outside it, being unnatural but in a natural way (Foucault, 2003). At the end of the 18th century and in the beginning of the 19th century, the human monster in its ambiguous form has become common. Foucault writes: "The monster is the fundamental figure around which bodies of power and domains of knowledge are disturbed and reorganized" (Foucault, 2003, p. 64). Up to the middle of the 18th century, monstrosity in itself was criminal, and, at the end of the century, the "moral monster" became a figure in the gothic novel, Foucault continues (2003, p. 75). During the 18th century, a development of the mechanism of punishment took place:

"Crime, then, is no longer only the violation of civil and religious laws; it is no longer only a violation of civil and religious laws that is thereby a potential violation of the laws of nature themselves. Crime now has a nature" (Foucault, 2003, p. 90).

Thus, because crime then entered the domain of nature, a natural history had to be created (Foucault, 2003, p. 90). Since the Roman law, the criminal was regarded as "disease of the social body" (Foucault, 2003, p. 90), and this aspect was also present in Montesquieu. At the end of the 18th century though, this changed into the view that it might be the criminal who is ill, something that became clearer in the work with the new penal code around 1790-1791: "the first moral monster to appear is the political monster. That is to say, crime is pathologized" (Foucault, 2003, p. 92). However, the criminal in the years before and during the revolution shared, as it were, something with the despotic monarch: they were both regarded as outlaws, the "sovereign above the law and the criminal beneath it," and this connection was tightened at the time for the September massacres in 1792 and the trial against Louis XVI in January 1793 who became "the first great juridical monster" (Foucault, 2003, pp. 95-96). This opened for questions about the monstrous criminal being somebody who might not be a matter for law at all: "the born criminal, has never actually subscribed to the social pact: Is he then a matter for law? Should the laws be applied to him?" (Foucault, 2003, p. 96). This led to the question about the monster being a sort of free prey (Foucault, 2003, p. 96). Is it this view of the human "monster," making the electric experiments possible, that allowed for the human to explore "the deepest mysteries of creation," that Shelley wants to illustrate in her novel?

\section{Mary Shelley's Interest in Science}

Mary Shelley (Figure 3) got in contact with the contemporary debate on galvanism early on. She was the daughter of the influential philosophers and authors William Godwin (1756-1836) and Mary Wollstonecraft (1759-1797), and their home was a focal point for engaging discussions about contemporary science. Mary Shelley, for instance, got to hear the story about Giovanni Aldini, nephew of Luigi Galvani, and his experiment on the corps of a late criminal who was sentenced to death for having drowned his wife and child in one of the canals of London (he was later proved to be innocent) (Nilsson, 2013; Mazzarella, 2014). Electric shocks on the head made the eyes open, and the face to start to grimace at same time as the head moved back and forth-but nothing happened when the electric shocks were on the heart, the corps remained lifeless. Probably, Mary Shelley based her Frankenstein on Aldini, somebody who had made an impression also on her husband, the poet Percy Bysshe Shelley. In what way is this reflected in the novel?

Frankenstein makes use of the electricity from a lightning strike when resurrecting the lifeless body of the Creature (put together by different parts of corpses Frankenstein found in mortuary). Like Prometheus who stole the fire from the gods in the mythology of Ancient Greece and gave to the humans because they were superior to all other animals, Frankenstein seized the power to create. Prometheus was tied to a rock guarded by an eagle or a vulture. Heracles eventually freed him. Prometheus theft became the origin of art and science. Frankenstein is also punished, at the moment the Creature escapes him and runs out into the world to eventually succumb on Walton's ship. Perhaps one can imagine a deep interest, more or less conscious, in the young Mary for the new scientific experiments. She had lost her mother who died giving birth to her and, in the end, had to grow up with a stepmother to whom she had no close relationship. Mary was very much preoccupied with the memory of her mother, with whom she had striking resemblances. Her father often took her to her mother's grave (Mazzarella, 2014).

\section{FRANKENSTEIN, THE NOVEL AND SCIENCE}

The main character in Shelley's novel is the young scientist Victor Frankenstein. Frankenstein, already as a schoolboy in Geneva, got obsessed by the natural philosophy, and this interest leads eventually to an almost compulsory dream about creating human life. Nobody shares this fantasy and ambition with him at the university in Ingolstadt where Frankenstein has been studying natural philosophy (Mazzarella, 2014). He was especially taken by the latest scientific discoveries within 


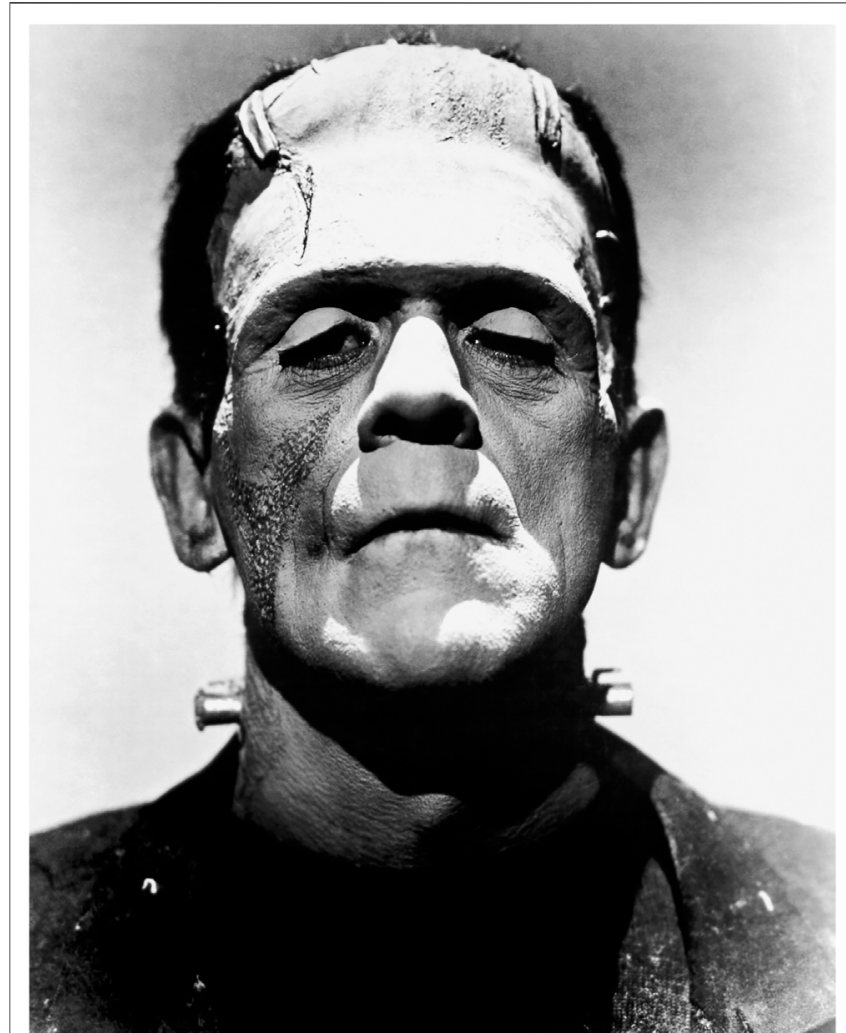

FIGURE 4 | Boris Karloff from "The Bride of Frankenstein" as Frankenstein's monster. Page URL: https://commons.wikimedia.org/wiki/File \%3AFrankenstein's_monster_(Boris_Karloff).jpg.

galvanism and electricity (Hindle, 2003, p. xxxvi). Frankenstein's obsession takes form:

"No one can conceive the variety of feelings which bore me onwards, like a hurricane, in the first enthusiasm of success. Life and death appeared to me ideal bounds, which I should first break through, and pour a torrent of light into our dark world. A new species would bless me as its creator and source" (Shelley, 1831, p. 55).

Frankenstein thus decided to ignore his teachers and to transcend the creation and its Creator. As a reader, we cannot know if he is a believer or not. However, if we might agree upon that Frankenstein had appropriated the materialism of, for instance, the influential La Mettrie fully, then he would think that there was nothing to stop him (or other people) from entering the role as "creator" with the keys to "the deepest mysteries of creation" (Shelley, 1831, p. 49). This question reflects the scientific project of the 18th century of which Frankenstein wanted to be a leading part of. During the 17 th and 18th centuries, there was, at the same time, a growing interest in human rights, as those were formulated at time in, for instance, The Declaration of the Rights of Man and of the Citizen of 1789 (although not all subjects were embraced by the Declaration at that time). In respect to religious narratives of the creation, the conflict involves the capacity of science, on the one hand, and the position of the human being in the Creation, on the other hand. Shelley's message is complex to its nature, as she regards the question about what it is to be human from two perspectives: Frankenstein's and the Creature's. The complexity of her message has psychological implications as well.

\section{FRANKENSTEIN AND HIS CREATURE, IN LIGHT OF PSYCHOLOGY}

The fact that humans assume the right to conduct experiment on other human being was not new at the time for Shelley's novel. The Italian Franciscan monk Salimbene (1221-1290), for instance, describes the emperor Frederick II's (1194-1250) "curiosity," or better perhaps, "excesses," when he conducted experiments on children (Coulton, 1906). An example before him was Psammetichus I (who reigned in Egypt between 664 and 610 BCE) described in Herodotus's (484-425 BCE) book Histories (published 430 BCE) (Coulton, 1906). In Herodotus's book, Psammetichus I left two children to a shepherd who got the instruction to take care of them, but he was not allowed to speak with them. The aim of the experiment was to register the first word the children would utter, so the shepherd was to listen carefully. That way, Psammetichus I would get the answer to the question what human language was the original one. When one of the two children uttered something, with the arms outstretched, the shepherd interpreted the word to be "bread" in Phrygian. Psammetichus I concluded that Phrygians were more ancient group than the Egyptians and that Phrygian was the human original language. According to Salimbene, Frederick II was inspired by Psammetichus I's question and had children from less well-off families locked in a cellar and gave his servants the instruction not to talk to them or in any other way give them any expression of affection. Frederick II wanted to know which of the classical languages Greek, Latin, or Arab the children would start to use "naturally". His hypothesis was that the human being was "pre-programmed" with one language; the question was only with which one (Coulton, 1906). The result, according to the story, was that the children did not learn any language at all, if they survived the cruel and inhuman treatment (Coulton, 1906).

In modern times, similar studies with rhesus monkey infants have been done by the psychologist Harry Harlow in a series of recognized experiments. The research took place at the University of Wisconsin-Madison where Harlow took several newborn rhesus monkey infants from their mothers and put them in a cage where they became socially isolated, the "pit of despair," together with an artificial surrogate mother. The monkey infants spent 24 months in that cage without meeting other monkeys. The surrogate mothers could be construed a bit differently, one was "hard" and made of wires with a square head, provided with a nursing bottle from which could feed the rhesus infant. The other surrogate mother, on the other hand, was dressed in a sort of fur, generated body heat, and could rock the rhesus infant. It turned out that the rhesus infants preferred the latter, thus the feeding mechanism of the surrogate mother was of a subordinated 
importance. However, the rhesus monkey infants developed severe disturbances after the treatment. The experiments showed that the rhesus infants, at all costs, tried to establish a relation to the surrogate mother and that the bodily contact was the most essential in these attempts. The experiments also showed that learning is dependent on a sense of security and curiosity and that human needs are also far more complex than sleep and food. However, the criticisms directed toward the "inhumanity" of Harlow's experiments grew-many people thought he had taken it too far. This gave rise to an increased awareness of the cruelty of animal experiments. The results of Harlow's experiments not only can illustrate the complexity of rhesus monkey infants but also can draw important conclusions in connection to human beings as well. Research in the Attachment theory in modern psychology is dedicated to the issue of the importance of contact between child and caregiver.

Mary Ainsworth's and John Bowlby's work within the Attachment theory focused on patterns in children's attachment to their caregivers. They started to cooperate in the 1950s, a cooperation that lasted for many decades (Broberg et al., 2006). Ainsworth's concept of "secure base" is of special interest here. Ainsworth's and Bowlby's work taught us that the child needs a "secure base" to return to when he or she out of curiosity starts to explore the world bit by bit. Within psychology, research has shown that, when the child lacks a caregiver who can attach to the child and tune in its needs, the consequences are negative in terms of mental health. The need for attachment, as Harlow's experiments on rhesus infants showed, is thus as valid for human infants (Broberg et al., 2006; Wennerberg, 2010).

\section{MARY SHELLEY'S FRANKENSTEIN IN FILM: THE EXAMPLE OF 1931 VERSION}

The scene where the Creature comes to life is central to the narrative in the novel and therefore interesting to compare with later adaptations of it to film. In the novel, the scene is played down in comparison to the film adaptations to come. The first fiction film adaptation, "Frankenstein" (Whale, 1931), is an example of this. Shelley describes the night in that tower house when Frankenstein at last succeeds in bringing life in the lifeless body. Frankenstein had worked arduously on his experiment; selfishly, he neglects his close relations and devotes all his energy and time to his obsession to reach success. Exhausted, Frankenstein describes his "big" moment:

"It was on a dreary night of November, that I beheld the accomplishment of my toils. With an anxiety that almost amounted to agony, I collected the instruments of life around me, that I might infuse a spark of being into the lifeless thing that lay at my feet. It was already one in the morning; the rain pattered dismally against the panes, and my candle was nearly burnt out, when, by the glimmer of the halfextinguished light, I saw the dull yellow eye of the creature open; it breathed hard, and a convulsive motion agitated its limbs" (Shelley, 1818, Chapt. V, p. 104).

Not much is said about the method in the experiment to bring the lifeless body into life, other than that an "instrument" is used. Frankenstein describes the pregnant moment with great anguish. Frankenstein does not ask himself whether the Creature's life has other meaning to than fulfilling his own search for glory and knowledge. Things are different in film adaptation of 1931 (Whale): the "bringing-to-life scene" is given a more central role due to its increased dramatic form. Elizabeth (Frankenstein's fiancée), Victor (the best friend, called Henry in the novel), and Dr. Waldman (Frankenstein's teacher) come to visit Henry Frankenstein in the old castle to which he had withdrawn (Victor in the novel) the stormy night when Frankenstein is fully preoccupied with preparing the experiment. The setting is dramatic; Frankenstein has a wild look in his face when he lets his guests into his laboratory, and the thunder is heavy outside when he opens the sunroofs and hoists up the examining table. The lifeless body is hit by the lightening. Frankenstein brings down the table and stares at the body and he sees the hand moving, and Frankenstein, in the movie, utters the famous words: "It is alive, it is alive [...] In the name of God, now I know how it feels to be God!” (Whale, 1931).

These words were censored eventually in the 1930s because of blasphemy. In later restored versions of the film, the noise from the thunder that earlier had covered Frankenstein's famous uttering was removed. The important role that the film adaptation (including later adaptations) gives to the scene in comparison to the more modest position Shelley that gives it may strengthen the idea that neither Frankenstein nor science as such was the most important to her. However, what might have been central to her was the question about the Creature and his destiny. The Creature is born into this world like a child and is bereaved of the love that he has the right to. This turns the Creature into a monster. Frankenstein's neglect of his fatherly obligations toward his creature and his and others' rejections created hatred in the Creature.

In addition, the end scene in the 1931 film version (Whale) differs a lot from the novel. In the novel, as we have seen, Frankenstein, worn down, succumbs in the cabin on Walton's ship from where, upon entering, Walton sees the Monster flee from the window. In Whale's version (1931), the Monster succumbs instead, in a mill into which the villagers have chased him as a revenge for the horrible crimes that he committed. Frankenstein follows his Creature into the mill and is caught by the grunting monster in a dramatic scene, but he succeeds in running away from him. The villagers set fire to the mill and the Monster is engulfed by the flames at the joy of the villagers cheering on the ground. The Hollywood end was a happy one, Frankenstein escaping the monster (Mazzarella, 2014). The story of the Creature is not told in the film and not in the later version "Victor Frankenstein" (McGuigan, 2015), to give yet another example. Thus, in addition, Mary Shelley's intentions with her novel are, to some extent, lost. Her interest in human relations, the central theme of the book, seems to be played down in the film adaptations. To Shelley, life was not just a 


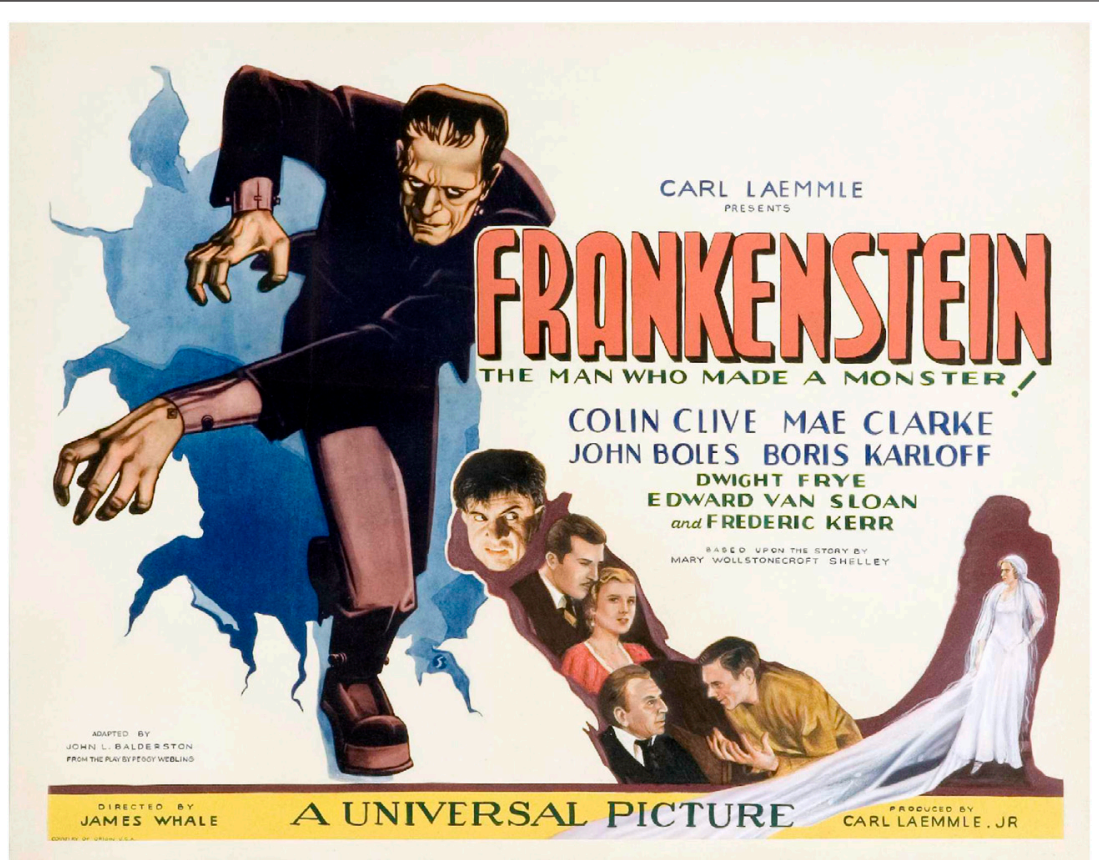

FIGURE 5 | Lobby card for the 1931 film "Frankenstein." https://commons.wikimedia.org/wiki/File\%3APoster___Frankenstein_02.jpg.

biological phenomenon. Frankenstein meets his creature, who reproaches him:

"How can I move thee? Will no entreaties cause thee to turn a favorable eye upon thy creature, who implores thy goodness and compassion? Believe me, Frankenstein: I was benevolent; my soul glowed with love and humanity: but am I not alone, miserably alone? You, my creator, abhor me; what hope can I gather from your fellow-creatures, who owe me nothing? They spurn and hate me. The desert mountains and dreary glaciers are my refuge. I have wandered here many days; the caves of ice, which I only do not fear, are a dwelling to me, and the only one which man does not grudge" (Shelley, 1818, chapt. X, p. 186).

Through the film adaptations, Frankenstein has become a symbol for biology as an engineering art, and for the scientist that plays God in his laboratory (Figures 4,5 ). It was not this kind of art that was "divine" for Shelley, but rather the one that the Monster discovers when he encounters human communication:

"By degrees I made a discovery of still greater moment. I found that these people possessed a method of communicating their experience and feelings to one another by articulate sounds. I perceived that the words they spoke sometimes, produced pleasure or pain, smiles or sadness, in the minds and countenances of the hearers. This was indeed a godlike science, and I ardently desired to become acquainted with it" (Shelley,

1818, chapt. XII, p. 211).

On the backdrop of the above, it is not perhaps too hasty to assume that Mary Shelley herself rather sided with Frankenstein's monster, who sought closeness and warmth from his fellow beings, than with Frankenstein who becomes the real monster of the novel. Language is given a central role. Frankenstein's creature is fascinated by human communication and makes efforts to learn the language. Linguistic communication is only humans endowed, and we have always been preoccupied to find a scientific explanation for language, from the time of Psammetichus I's experiment to the highly technological experiments of today.

\section{CONCLUDING REMARKS: FRANKENSTEIN, THE MONSTER?}

Some aspects of the Creature that Shelley wanted to mediate in her novel are lost, and thus, the focus has shifted to Frankenstein the scientist and his relation to science, but at the expense of his relation to his creature.

In, perhaps, the most known film version from 1931 (Whale), the Frankenstein character is dominated by his role as a scientist and the "playing God" sides to it, which seems not to have been as important to Shelley. Moreover, the ending in the film, being very much altered in comparison to how Shelley ended the novel, suggests that the view of the "criminal" in the public opinion also changed in hundred years. After the September massacres in 1792 , monstrous criminals were those who were regarded as 
being outlaws, no matter if it concerned the despotic monarch above the law or the criminal beneath the law: both had not committed themselves to the social contract. In Shelley's novel, Frankenstein and his monster are both condemned to a life outside society, and Frankenstein to a premature death. Following Foucault (2003), Frankenstein seems here to represent the "moral monster," and the Creature the "pathologized" monster-although not born a criminal but becoming one, due to the severe neglect of his creator. The latter being one of the main points Shelley wanted to convey in her narrative.

In the ending of the film of 1931 (Whale), Frankenstein is let into the society again and only the Monster is condemned as a criminal, being a free prey to the villagers. The Monster thus might still represent the "pathologized" monster-but a natural one being-outside the "matter of law" (Foucault, 2003), an Alius, but Frankenstein seems to be freed from his moral responsibility of his Creature: at the point, the Monster is gone, Frankenstein is forgiven for his “playing God" act. This aspect, Frankenstein's responsibility for the Creature being lessened, seems to have become the most conspicuous today in the debate and in the popular culture. Many scientific books and articles have titles that refer to Frankenstein more from this angle, for instance: Frankenstein's footsteps, The Frankenstein syndrome, "The Frankenfood myth" or, as in the title of an interview with the geneticist J. Craig-known for his research in advanced synthetic

\section{REFERENCES}

Broberg, A., Granqvist, P., Ivarson, T., and Risholm Mothander, P. (2006). Anknytningsteori. Betydelsen Av Nära Känslomässiga Relationer. Stockholm: Bokförlaget Natur \& Kultur.

Coulton, G. G. (1906). "St. Francis to Dante," in Medieval Sourcebook: Salimbene: On Frederick II, 13th Century, 242-243. London: David Nutt. Available at: https://sourcebooks.fordham.edu/source/salimbene1.html (Accessed June 10, 2017).

Eco, U. (1990). "Interpretation and Overinterpretation: World, History, Texts," in The Tanner Lectures on Human Values (Cambridge: Delivered at Clare Hall, Cambridge University). Available at: https://tannerlectures.utah.edu/_ documents/a-to-z/e/Eco_91.pdf (Accessed May 29, 2021).

Foucault, M. (2003). Abnormal: Lectures at the College de France 1974-1975. London and New York: Verso.

Hindle, M. (2003). "Introduction," in Frankenstein or the Modern Prometheus. Editor M. Hindle (London: Penguin Books).

Mazzarella, M. (2014). Själens Nattsida: Om Mary Shelley Och Hennes Frankenstein. Stockholm: Atlantis.

McGuigan, P. (2015). Victor Frankenstein. United Kingdom: Moving Picture Company (MPC).

Nilsson, M. (2013). Frankensteins Elektriska Monster. Makabra experiment Födde Världens Mest Kända Skräckfigur. Allt Om Vetenskap. Available at: http:// www.alltomvetenskap.se/nyheter/frankensteins-elektriska-monster (Accessed June 12, 2017).

Presskorn-Thygesen, T. (2012). "Samfundsvidenskabelige Paradigmer - Fire Grundlaeggende Metodiske Tendenser I Moderne Samfundsvidenskab," in Samfundsvidenskabelige Analysmetoder. Editor C. Nygaard (Frederiksberg: Samfundslitteratur), 21-48.

Rédei, A. C. (2007). An Inquiry into Cultural Semiotics: Germaine de Staël's Autobiographical Travel Accounts. [dissertation]. Lund: Lund University. ISBN: 978-91-628-7109-3. biology, which resulted in the first artificially created DNA molecule in 2010-"J. Craig Venter talks life, ego, ambitions-and Frankenstein." Might that be due to the fact that, today, in our sociocultural context, Frankenstein seems to be easier to forgive, as the end of the enormously popular film version of 1931 (Whale) suggests. Frankenstein is still a monster playing with the fire, but being less monstrous as the technique advances.

\section{DATA AVAILABILITY STATEMENT}

The original contributions presented in the study are included in the article/Supplementary Material, further inquiries can be directed to the corresponding author.

\section{AUTHOR CONTRIBUTIONS}

The author confirms being the sole contributor of this work and has approved it for publication.

\section{FUNDING}

This work was supported by Voucher Jessica Abbott.

Ricoeur, P. (1970). Freud and Philosophy: An Essay on Interpretation, Trans. New Haven and London: Yale University Press.

Shelley, M. (1831). Frankenstein, or the Modern Prometheus. Editor M. Hindle (London: Penguin Books).

Shelley, M. (1818). Frankenstein, or the Modern Prometheus. London: Lackington, Hughues, Harding, Mavor, \& Jones. Available at: http://www.gutenberg.org/ ebooks/42324 (Accessed June 11, 2017).

Sonesson, G. (2016). "Lifeworlds: The Cognitive Semiotics of Culture," in Human Lifeworlds: The Cognitive Semiotics of Cultural Evolution. Editors D. Dunér and G. Sonesson, 23-61. (Lausanne: Peter Lang Publishing Group).

Wennerberg, T. (2010). Vi Är Våra Relationer: Om Anknytning, Trauma Och Dissociation. Stockholm: Bokförlaget Natur \& Kultur.

Whale, J. (1931). Frankenstein. United States: Production Company Universal Pictures.

Wright, A. (2013). Monstrosity: The Human Monster in Visual Culture. London \& New York: I. B. Tauris.

Conflict of Interest: The author declares that the research was conducted in the absence of any commercial or financial relationships that could be construed as a potential conflict of interest.

Publisher's Note: All claims expressed in this article are solely those of the authors and do not necessarily represent those of their affiliated organizations, or those of the publisher, the editors and the reviewers. Any product that may be evaluated in this article, or claim that may be made by its manufacturer, is not guaranteed or endorsed by the publisher.

Copyright (c) 2022 Rédei. This is an open-access article distributed under the terms of the Creative Commons Attribution License (CC BY). The use, distribution or reproduction in other forums is permitted, provided the original author(s) and the copyright owner(s) are credited and that the original publication in this journal is cited, in accordance with accepted academic practice. No use, distribution or reproduction is permitted which does not comply with these terms. 